\title{
Ethical Fishing Aboard the Miami Science
}

Joshua Coco Derek Sheldon*

University of Miami, USA

Submission: May 23, 2017; Published: April 26, 2018

*Corresponding author: Joshua Coco Derek Sheldon, University of Miami, 1100 S. Miami Ave. Unit 3005, USA, Tel: 5614601019;

Email: joshua.coco@gmail.com

\section{Introduction}

Background: Recreational fishing is a multi-billion dollar industry in the state of Florida according to the Florida Fish and Wildlife Commission (FFWC). In recent years recreational saltwater fishing license sales have exceeded a count of 1.5 million annually. With millions of people taking to the water every year to try their luck in some of the best fishing waters around the water, there is a significant need for angler education about the legal, ethical, and sustainable implications that surround angling in south Florida.

Shown in Figure 1, the Miami Science Barge (the Barge) has been docked on the waters of Biscayne Bay just north of downtown Miami since April of 2016. The only program of its kind in Miami-Dade County, this 4,000 square foot platform operates research-scale systems for sustainable aquaculture and agriculture, renewable energy, environmental restoration, and water conservation. Winner of the inaugural Knight Foundation Cities Challenge, the Barge provides free field trips to MiamiDade County Public schools Monday through Friday. While these children are taught the "what" and the "why" in school, the field trips empower them to discover the "how" through hands-on experimentation and questioning in concurrence with Florida's Common Core Standards . Striving to supplement traditional science education by focusing on scientific literacy as a key component of a larger set of core societal competencies, the Miami Science Barge believes, "like Paul DeHart Hurd before them that scientifically literate students should be able to understand and respond critically to issues with a science component, while being equipped with the necessary tools to develop and express their personal point of view on these issues ." Through the development of their very own STEMIS (Science Technology Engineering and Mathematics In Society) curriculum they aim to be the complementary source of education that enables students from around Miami to be critical consumers of scientific information and engage in effectual public dialogue . Additionally, the student curriculum seeks to shed light on socioscientific issues with a sense of immediacy in South Florida . Upon coupling these core functions with the existing public weekend programming framework, the Barge presented itself as an ideal location to educate anglers through an engaging series of seminars designed to educate community members about angling in our waters.

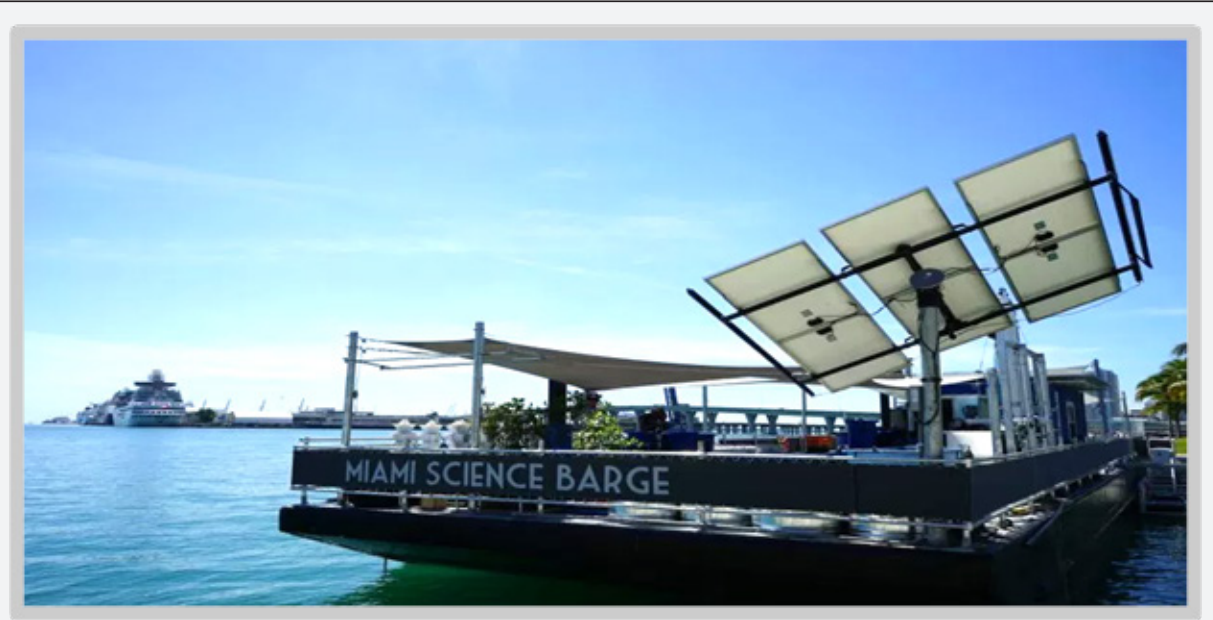

Figure 1: Miami Science Barge Platform, Retrieved from The New Tropic web article.

${ }^{1}$ Myfwc.org

${ }^{2}$ Miamisciencebarge.org

${ }^{3}$ ibid

${ }^{4}$ Braus, 1995

Oceanogr Fish Open Access J 6(3): OFOAJ.MS.ID.555689 (2018) 


\section{My Internship}

My internship with the Miami Science Barge started in August of 2017 and originally focused on systems maintenance for the recirculating aquaculture, hydroponic, aquaponic, and coral/wetland restoration systems. Upon arriving, I immediately asked to become more engaged with the education side of side of Barge operations. This put me on a path to leading school field trips and designing my own curriculum, which we later labeled STEMIS (Science Technology Engineering and Mathematics in Society) to ensure that there was an emphasized focus on utilization of learned materials in our communities.

After my first foray into curriculum design I became interested in using the Barge's public programming opportunities as a way to engage the public with hands-on science that they would be excited to take back to their homes and their jobs. This interest birthed my grant writing experience with the Miami Science Barge. Over the course of the next three months I wrote four separate grant applications, one of which can be found in Appendix 1, while also fulfilling my assigned duties as mechanic and educator. The Fish Florida grant, as it came to be called, was my attempt at integrating public outreach, experiential education, and conservation into a solution for Miami's issues with recreational fishers.

\section{Statement of Problem}

With millions of anglers exerting fishing pressure on the waters of south Florida every year there is an apparent lack of ethical and legal education prior to letting people handle the fish they are catching. Upon observing fishers in Miami communities I began to notice unsettling trends in their catch, cleaning, and release habits. Many anglers would keep fish that were not within the legal size limits, fillet fish in a wasteful manner, or would even release fish in such a way that the animal would not survive post-catch. Additionally, after speaking with a number of local anglers I was able to tease out a select number of stereotypes associated with these bad habits.

Recreational anglers in Miami are thought to be wasteful with the fish they choose to keep. They are thought to be unethical in how they handle and release the fish that they return to the water . They are thought to ignore legal size, bag, and seasonal limits, and they are thought to be unaware of the multitude of conservation efforts happening around them . Whether these issues are the result of ignorance, blatant disregard, or misinformation, herein lays an opportunity to engage with local anglers in an attempt to begin solving the problem. So how can we educate local anglers in a way that will be engaging and memorable, while also preparing them to go into their communities and begin a discourse about what they have learned?

${ }^{5}$ Miami Science Barge TD Bank Grant

${ }^{6}$ ibid

${ }^{7}$ Arlinghaus, 2007

${ }^{8}$ myfwc.org

\section{Purpose and Significance of Seminar}

The Miami Science Barge's Ethical Fishing Series will present local anglers ages 13 and up with a hands-on set of seminars to practice essential skills for sustainable and ethical fishing, such as waste reduction, removal of invasive species, and best practices for handling non-extracted species. Directly addressing the issues of lack of education and disregard for legality and ethics, the series will be geared towards aspiring young fishers and their parents in an attempt to engage entire families so that sharing best practices and policing bad behavior goes all the way home to the dinner table.

The Barge believes that part of the answer to the lack of angler education lies outside the traditional classroom, where most learning is abstract and problem-based. Experiential (or "hands-on") education motivates their participants by engaging them in a solution-based approach to "real world" challenges within their local community. Miami's unique ecological assets are powerful learning tools to promote conservation education, but they are vastly underutilized in our city.

The Barge functions to ensure that citizens have access to high-quality experiences that will change the way they look at their city, and at the same time energize them to be responsible stewards of the environment. Onboard the Miami Science Barge during the seminars we will strive to ingrain a sense of ownership within participants; ownership of their shared resources, ownership of their actions, and ownership of their Miami. Establishing this sense of ownership is an integral step towards developing action-oriented citizens; citizens who would rather speak up for what is theirs than sit by and let it slip through their fingers.

With this in mind, the Miami Science Barge will serve as the nexus for experiential education and angler engagement. By utilizing this space the crew will start to instill recognized best practices for fish handling, fish cleaning, and invasive removal in our participants through hands-on activities. We plan to make conservation science accessible, immediate, relevant and fun.

\section{Description of Seminar Series}

The seminar series will be presented in three installments, each with their own experiential component to ensure engagement and retention of learned information. Each seminar will address different key issues derived from observed behaviors of local anglers, and noted to be of ecological or economic importance.

\section{Objectives}

Educate community members about the following topics:

I. Filleting techniques to reduce waste 
II. The importance of eating locally

III. The importance of eating sustainably caught/farmed seafood

IV. The lionfish invasion into the Caribbean Basin and Gulf of Mexico

V. Safe removal and handling of lionfish

VI. Threats that invasive species pose to native species and their environments

VII. Legal implications of fishing in south Florida

VIII. Proper species identification for commonly confused species

IX. Proper measurement techniques for commonly extracted species

X. Best practices for catch and release handling of fish

XI. Physiological stress response in at-risk species such as hammerhead sharks and sawfish.

\section{Funding process}

Cover letter and official proposal submitted to the "fish florida grant opportunity": Appendix 1 shows the official proposal for the Miami Science Barge's Ethical Fishing Seminar Series, which was wholly planned and written for the Miami Science Barge as the internship project. Reviewing previously written grants in the Miami Science Barge database, and conferring with the grant review team at Fish Florida helped to complete the proposal in just under a month to meet the November 1, 2016 deadline. Collaborating institutions such as University of Miami's Shark Research and Conservation Program and Field School also submitted letters of commitment found in Appendixes 2 \& 3.

Results

\section{Results of grant application}

Funding in the amount of $\$ 4,000$ for the seminar series was secured in February of 2017 through the generosity of Fish Florida, which stated, "it's not every day that we get a proposal that comes across our desk and the first sub-title is knife skills. We were caught off guard in the best way, and are very excited to be a part of this opportunity." The budget found in Appendix 4 was then approved for cost allocation.

\section{Planning process}

Upon approval of the aforementioned budget the planning process for the first three sessions began immediately. This included scheduling of presenters and collaborators including the REEF Foundation, Double Threat Charters, and Field School, each to lead a number of hands-on activities during their allotted seminar. Additionally, the sourcing of all necessary materials for the first installment was completed prior to the execution of the first seminar. These materials included; non-latex nitrile gloves, fillet knives, paralyzer spear tips, lobster gauges, 20 pounds of whole lionfish, and over 20 pounds whole assorted finfish.

\section{Execution}

The first session of installment one has been completed and the following two sessions have been scheduled. Session One ran on March the 18th from 11am-1pm and showcased a 45-minute presentation by Ellie Splain of the REEF Foundation. This presentation focused on the invasive Pterois volitans (one species of Indo-Pacific Lionfish) and covered topics such as; how the fish invaded, how they are impacting the local environment, and what can be done to stop them. The presentation was followed by a roughly one-hour hands-on crash course in how to safely remove, handle, and fillet lionfish. The session was capped at 25 individual participants due to limitations of available space and the participant age demographic ranged between 13 and 55 years old with each sex being equally represented among teens, young adults, and adults. Three separate families attended the event, making up exactly one half of all participants, and the remaining individuals attended in groups of two or more. The session was not without its challenges, highlighted by a near inability to obtain fresh lionfish due to last minute cancellations by suppliers, however attendees widely regarded the session as highly informative and everyone was able get their hands on a lionfish in some capacity. One participant was even noted as saying, "I never thought I'd learn this much about lionfish. I bet I know even more than you do now, Derek!" Watching the children focus on safely handling the fish and fillet around the venomous spines with the encouragement of their parents was the highlight of the session. This, in the very first session, showcased exactly what the seminar series was envisioned to bring to the community. Session two is scheduled for April 15th and session three has a TBD date due to managerial changes within the Barge.

\section{Metrics and Measurables}

Series participants were presented with the surveyupon completion of each seminar to gauge the effectiveness of the activities and presentations. Surveys focused on the level of engagement that the seminars had, the ability of the seminars to present information in an attractive and understandable way, and the participants' willingness to discuss and disseminate what he or she learned over the course of the series. The results of these surveys have yet to be complied for use by the Frost Museum of Science for reporting to the Fish Florida Foundation [1-5].
${ }^{9}$ ibid

${ }^{8}$ Cooke, 2004 


\section{Limitations and Additional Opportunities}

The series took place aboard the Miami Science Barge, which limits the number of attendees at each seminar. With safety as a primary concern, the available space for teaching attendees to properly use fillet knives and handle venomous fish led to a cap of 20-25 participants per session. However, this presents the opportunity for additional series to ensure that greater numbers of community members can participate, and those in attendance at each seminar can receive more in depth, personalized instruction.

Additionally, the scope of the information covered could be broader with regards to ecology and existing research. Attendees exhibited higher degrees of understanding than anticipated when presented with complex topics and at times it felt as though the information presented was fairly based in common sense. Nonetheless, this lack of detailed scientific coverage could be supplemented by additional seminars that will produce increased and prolonged visibility for the Miami Science Barge [6-10].

Limitations presented by restrictions of funds created a number of unavoidable last minute changes that may have led to attendee frustrations regarding timeliness of the events, and number of giveaway items available at the end of each session. This, above all else, made the necessity for increased fundraising efforts abundantly clear and heightened the Barge's conscientiousness for effective grant writing and securing funds in a timely manner.

Finally (for the purposes of this paper at least), connecting with the ideal presenters proved difficult in many cases. This was a product of a number of issues ranging from unresponsiveness to continued scheduling conflicts, and the inability to have certain presenters attend seemingly limited the effectiveness of certain aspects of the seminars. Nonetheless, this created an immense opportunity for Miami Science Barge staff and crew to fulfill the role of supplemental educators and showcase the knowledgebase that exists within the ranks. Everyone from volunteers all the way up to systems managers seized the opportunity to engage attendees and begin a passionate and personalized dialogue about sustainable fishing that will hopefully extend beyond these two-hour sessions.

\section{Lessons Learned}

Never in my wildest dreams would I have anticipated learning as much as I did in my time with the Miami Science Barge. When I started as a systems tech I did not know at all what to expect of my next nine months, but the results have already had a profound effect on my life. With that being said, the three key lessons that I learned through the brainstorming, planning, and executing of the Sustainable Fishing Series are as follows:

1. Always have a back up plan. When it seems as if everything that could have gone wrong has gone wrong, it makes the implosion feel much smaller when you know that there is at least a contingency plan in place.

2. Plan for delays. Whether it be delays in receiving funding, delays in response from the necessary organizations, or delays in receiving the necessary materials, delays will happen. Building slack into your schedule makes these delays just apart of the process.

3. The relationships you build with your coworkers are your safety net. Things will not always go your way, and when they don't, it always helps to have people that you can rely on to help get things back on track. Although doing things on your own may seem noble, asking for help at the right times can make things one hell of a lot easier.

\section{Conclusion}

Upon completion of the first two sessions of the seminar series a number of conclusions began to reveal themselves through analysis of attendee satisfaction surveys and participant observation.

A. The Sustainable Fishing Series has engaged over 40 individual attendees in only two sessions with 7 more sessions yet to be scheduled.

B. Attendees have reported high levels of satisfaction with the events and medium-high levels of intent to change their current behavior.

C. Miami has an affinity for experiential education, but the Barge can only serve a small subset of the community.

D. Cooperation between the various institutions within the community must be a tenet of their operations to ensure effectiveness.

These conclusions have shed light on the shortcomings and successes of the series and will hopefully shape the next seven sessions to ensure their effectiveness.

\section{References}

1. Arlinghaus R, Cooke SJ, Lyman J, Policansky D, Alexander Schwab, et al. (2007) Understanding the complexity of catch-and release in recreational fishing: an integrative synthesis of global knowledge from historical, ethical, social. Reviews in Fisheries Science 15(1-2): 75-167.

2. Baram-TA, Osborne J (2015) Bridging science education and science communication research. Journal of Research in Science Teaching 52(2): 135-144

3. Braus J (1995) Environmental education: where we've been and where we're going. Bioscience S45-S51.

4. Cooke SJ, Cowx IG (2004) The role of recreational fishing in global fish crises. Bioscience 54(9): 857-859.

5. Côté IM, Green SJ, Hixon MA (2013) Predatory fish invaders: Insights from Indo-Pacific lionfish in the western Atlantic and Caribbean. Biological Conservation 164: 50-61. 
6. Danylchuk A, Bachand J, Maxey C (2006) The Cape Eleuthera Island School: Immersion, Involvement, Ownership, and Legacy as principles to enhance education in marine science and beyond. $57^{\text {th }}$ Gulf and Caribbean Fisheries Institute.

7. Gallagher A, Serafy J, Cooke S, Hammerschlag N (2014) Physiological stress response, reflex impairment, and survival of five sympatric shark species following experimental capture and release. Marine Ecology Progress Series 496: 207-218.

8. Lyle ML, Moltschaniwskyj NA, Morton AJ, Brown IW, Mayer D (2007)
Effects of hooking damage and hook type on post-release survival of sand flathead (Platycephalus bassensis). Marine and Freshwater Research 58(5): 445-453.

9. Scyphers SB, Gouhier TC, Grabowski JH, Beck MW, Mareska J, et al. (2015) Natural Shorelines Promote the Stability of Fish Communities in an Urbanized Coastal System. PLOS ONE 10(6).

10. The Economic Impact of Saltwater Fishing in Florida.
Your next submission with Juniper Publishers will reach you the below assets

- Quality Editorial service

- Swift Peer Review

- Reprints availability

- E-prints Service

- Manuscript Podcast for convenient understanding

- Global attainment for your research

- Manuscript accessibility in different formats ( Pdf, E-pub, Full Text, Audio)

- Unceasing customer service

Track the below URL for one-step submission https://juniperpublishers.com/online-submission.php 